Canadian Journal of Higher Education

Revue canadienne d'enseignement supérieur

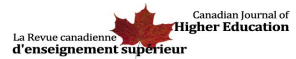

\title{
New Universities' Organizational Identities Through Presidential Lenses
}

\author{
John S. Levin, Ariadna I. López Damián, Marie C. Martin et Evelyn M. Vázquez
}

Volume 48, numéro 2, 2018

URI : https://id.erudit.org/iderudit/1057101ar

DOI : https://doi.org/10.7202/1057101ar

\section{Aller au sommaire du numéro}

\section{Éditeur(s)}

Canadian Society for the Study of Higher Education

\section{ISSN}

2293-6602 (numérique)

Découvrir la revue

Citer cet article

Levin, J., López Damián, A., Martin, M. \& Vázquez, E. (2018). New Universities’ Organizational Identities Through Presidential Lenses. Canadian Journal of Higher Education / Revue canadienne d'enseignement supérieur, 48(2), 20-38. https://doi.org/10.7202/1057101ar

\section{Résumé de l'article}

Cette étude qualitative s'occupe de trois nouvelles universités dans les provinces de la Colombie-Britannique et l'Alberta et l'utilisation d'identité organisationnelle de leurs présidents au contexte de leurs universités. Par les entrevues étendues semi-structurées et l'analyse narrative, cette étude emploie la théorie de l'identité organisationnelle et la théorie institutionnelle pour expliquer la positionalité et les vues des présidents à propos du chemin de la légitimité de leurs universités. La présente étude a trouvé que la préservation des anciennes identités des institutions (en tant que les collèges communautaires) aide le changement des nouvelles universités. En outre, même si les présidents ont préconisé de remplacer les logiques collèges communautaires, les données ont montré que ces trois universités n’ont pas encore adopté complètement la logique universitaire. Nous suggérons qu'un mélange des logiques peut être le moyen préféré pour atteindre la légitimité au cours des changements sectoriels dans le contexte des nouvelles universités.Cette étude qualitative s'occupe de trois nouvelles universités dans les provinces de la Colombie-Britannique et l'Alberta et l'utilisation d'identité organisationnelle de leurs présidents au contexte de leurs universités. Par les entrevues étendues semi-structurées et l'analyse narrative, cette étude emploie la théorie de l'identité organisationnelle et la théorie institutionnelle pour expliquer la positionalité et les vues des présidents à propos du chemin de la légitimité de leurs universités. La présente étude a trouvé que la préservation des anciennes identités des institutions (en tant que les collèges

communautaires) aide le changement des nouvelles universités. En outre, même si les présidents ont préconisé de remplacer les logiques collèges communautaires, les données ont montré que ces trois universités n’ont pas encore adopté complètement la logique universitaire. Nous suggérons qu'un mélange des logiques peut être le moyen préféré pour atteindre la légitimité au cours des changements sectoriels dans le contexte des nouvelles universités.
Copyright (c) John S. Levin, Ariadna I. López Damián, Marie C. Martin, Evelyn M. Vázquez, 2018
Ce document est protégé par la loi sur le droit d'auteur. L’utilisation des services d’Érudit (y compris la reproduction) est assujettie à sa politique d'utilisation que vous pouvez consulter en ligne.

https://apropos.erudit.org/fr/usagers/politique-dutilisation/ 


\title{
New Universities' Organizational Identities Through Presidential Lenses
}

John S. Levin, Ariadna I. López Damián, Marie C. Martin, \& Evelyn Morales Vázquez University of California, Riverside

\begin{abstract}
This qualitative investigation addresses three new universities in the provinces of British Columbia and Alberta and their presidents' ascriptions of organizational identity to their universities. Through extended, semi-structured interviews and narrative analysis, this investigation uses organizational identity theory and institutional theory to explain the positionality and understandings of presidents in relationship to their universities' paths to legitimacy. We found that the preservation of aspects of the institutions' original identity (as community colleges) aids new universities' organizational change. Furthermore, while presidents advocated for a replacement of community college logics with university logics, data showed that these three new universities had yet to embrace the university logic fully. We propose that a blending of logics may be the preferred mechanism for the attainment of legitimacy during sectoral change for new universities.
\end{abstract}

\section{Résumé}

Cette étude qualitative s'occupe de trois nouvelles universités dans les provinces de la Colombie-Britannique et l'Alberta et l'utilisation d'identité organisationnelle de leurs présidents au contexte de leurs universités. Par les entrevues étendues semi-structurées et l'analyse narrative, cette étude emploie la théorie de l'identité organisationnelle et la théorie institutionnelle pour expliquer la positionalité et les vues des présidents à propos du chemin de la légitimité de leurs universités. La présente étude a trouvé que la préservation des anciennes identités des institutions (en tant que les collèges communautaires) aide le changement des nouvelles universités. En outre, 
même si les présidents ont préconisé de remplacer les logiques collèges communautaires, les données ont montré que ces trois universités n'ont pas encore adopté complètement la logique universitaire. Nous suggérons qu'un mélange des logiques peut être le moyen préféré pour atteindre la légitimité au cours des changements sectoriels dans le contexte des nouvelles universités.

\section{Introduction to the Problem}

The enactment of provincial legislation that restructured British Columbia (2008) and Alberta (2009) higher education institutions from community colleges to universities (University Act and Post-Secondary Learning Act, respectively) led to alterations not only to mission and purpose but also to organizational identity for former community colleges in both provinces (Levin, 2017). This alteration included bicameral governance, the elevation of research as a function of the institution and a responsibility of faculty, and rank and tenure for faculty (Levin, 2017). Explanations of this alteration and its consequences are limited (Levin 2017; Levin, Aliyeva, \& Walker, 2016; Levin, López-Damián, Rall, Martin, \& Viggiano, 2016; Levin, Martin, López-Damián, Rall, \& Viggiano, 2016; Levin, Rall, Viggiano, \& López-Damián, 2016). These explanations have emanated from a comprehensive, amalgamated view or data set that includes both institutional documents from three individual universities and organizational members, including faculty and administrators (Levin, 2017; Levin, López-Damián, et al., 2016; Levin, Martin, et al., 2016; Levin, Rall, et al., 2016). Aside from these works, perspectives and thus meanings from individual participants are limited to the perceptions and experiences of one group of faculty, in one study, at one new university (Yeo, Bennett, Stoneman McNichol, \& Merkley, 2015). Given the formal role and the prominence accorded in scholarly literature to university presidents, their omission from scholarship on organizational change based on sectoral change-from community college to university-is a significant absence, especially given that they are the university administrators most responsible for the transition and the establishment of their institution as a university. As this alteration is a significant one in the development of universities in Canada, understandings gleaned from university presidents can fill in knowledge gaps about what scholars have termed new universities (Levin, 2017), and also add to the scholarship on Canadian university presidents.

\section{Purpose}

Our purpose was to explain the ways in which three presidents of new universities understand and articulate the organizational identity of their universities, as well as the ways in which these understandings shape their conceptualization of their own role in the organization. This qualitative inquiry uses elements from organizational theory (Morgan, 2006; Whetten, 2006) and institutional theory (Scott, 2014) to examine and explain the conceptions and projections of meaning of three presidents of new universities in Canada.

\section{Literature Review}

The scholarly literature on new universities in Canada that evolved from community colleges is limited (e.g., Levin, 2017; McQuarrie, Kondra, \& Lamertz, 2013; Yeo et al., 2015), and that on presidents of these institutions is nonexistent. Nonetheless, there is a 
substantial body of literature, particularly in the United States, on presidents, although the overwhelming body of that literature comes from the 1980s-90s (e.g., Birnbaum, 1992; Kerr \& Gade, 1986) and includes a few publications in Canada (e.g., Budros, 2002; Miller, 1998; Mount \& Bélanger, 2001; Muzzin \& Tracz, 1981).

University and college presidents remain an underexamined population in Canadian literature. What scholarship on presidents has been completed is dated and often U. S.centric, and reveals little about the presidents' perceptions of their organizations' identity and their role in relationship to that organizational identity. In addition to the characteristics of presidents (Budros, 2002; Green, 1988; Nicholson, 2007), researchers have explored the work-life balance of university presidents (Havice \& Williams, 2005), their career paths (Amey \& VanDerLinden, 2002; Birnbaum \& Umbach, 2001; Madsen, 2006; Moore, Salimbene, Marlier, \& Bragg, 1983; Wessel \& Keim, 1994), their compensation (Monks, 2007; Pfeffer \& Ross, 1988; Tang, Tang, \& Tang, 2000), their approaches to leadership and leadership traits (Birnbaum, 1989a; Dee, Henkin, \& Holman, 2004; Esters et al., 2016; Freeman \& Kochan, 2013; Padilla, 2005; Tierney, 1989), their power and influence (Baldridge, Curtis, Ecker, \& Riley, 1980; Birnbaum, 1988; Budros, 2002; Cohen \& March, 1974), how they learn and make sense of their role (Smerek, 2010), and their role in the perpetuation of, or resistance to, broader entrepreneurial (Mount \& Bélanger, 2001; Slaughter, 1993) and managerial (Miller, 1998) trends in higher education.

Why do presidents' understandings and perceptions matter, particularly with regard to organizational identity? Presidents as chief executive officers of universities are tasked with "planning, organizing, directing, and representing the institution" (Havice \& Williams, 2005, p. 128). They are "responsible for the overall leadership and administrative action" (Havice \& Williams, 2005, p. 128) within the institution, which includes resource management and public relations. Nevertheless, the responsibilities enumerated in a job description do not necessarily equate to actual, or actualized, influence or power.

Three primary stances on the influence and power of university and college presidents can be found in the literature. One body of literature asserts that university presidents' power is constrained, or limited, by other actors, such as governing boards, faculty, external actors, state or provincial government, and resource shortages (Birnbaum, 1988, 1989b; Budros, 2002; Cohen \& March, 1974; Levin, 1995). The literature that falls into the constraint category positions college presidents as symbolic leaders with diminished autonomy (Birnbaum, 1988; Budros, 2002; Tierney, 1989). In contrast, the second stance present within the literature contends that university presidents possess substantial power and influence over their organization (Baldridge et al., 1980; Budros, 2002; Clark, 1972). Miller (1998) asserts that powerful presidents have the ability to mitigate, mediate, and modify pressures from external sources such as the provincial government or board members. The third assertion about the role and influence of university and college presidents is that they have influence and power in some areas of their work but not in others $(\mathrm{Bu}-$ dros, 2002); that is, a president "both does and does not make a difference" (Levin 1992, p. 42). Whereas presidents are unable to influence or control the organization's programs and policies, educational planning, and financial conditions, "presidents [do] affect a college's culture and reputation" (Budros, 2002, p. 95). Conversely, an institution's culture and history can also impede the president's efforts (Levin, 1995). Furthermore, a president's effects may also be influenced by his or her relationships, organizational leadership 
succession, and the tolerance of stakeholders (Levin, 1995). Although the extent to which presidents possess and exert power continues to be contested, expectations for presidents are formidable. The president is expected to be the "lead visionary and strategist" (Freeman \& Kochan, 2013, p. 16) of the organization, as well as the "educational leader" (p. 28), and the "communicator of institutional orientations and actions" (Levin, 1992, p. 28).

Entwined with presidential power and influence is organizational identity (Scott \& Lane, 2000). There are hierarchical differences in perceptions of organizational identity (Corley, 2004), and top-level managers, such as presidents, play an assumed intrinsic role in the development of organizational identity (Scott \& Lane, 2000). While some research on presidents, such as Budros's (2002) study on retrenchment and strategic leadership, has critiqued other scholarship for reliance on "the perceptions of campus figures" (Budros, 2002, p. 92), other research has found that "social actor views of identity related processes [are] not only germane to the formation of organizational identity but...these processes [are] also mutually constitutive in creating a workable identity" (Gioia, Price, Hamilton, \& Thomas, 2010, p. 1). Then, presidents, if not contested, are a central source of information about the organizational identity of a university (Birnbaum, 1994), a source which to a lesser or greater extent shapes organizational identity, especially when the organization has faced or faces sectoral change, such as movement from college or community college status to university status.

\section{Theoretical Framework and Research Questions}

Organizational identity and organizational roles are both objective (formal) and subjective (informal) constructs (Albert \& Whetten, 1985; Evan, 1993). In this investigation, we focus on them as subjective notions. There is a connection between what individuals understand as a university's organizational identity and the way in which these individuals make sense of their own position within the organization (Whetten, 2006). That is, the organizational identity and the organizational role are mutually informing subjective constructs. Organizational members develop images of their organization that both elevate and ignore specific aspects of the organization and that lead individuals to manage organizations in distinctive ways (Morgan, 2006). Thus, the images that individuals in institutional positions (e.g., president, board of trustees) have of their organizations influence their own functions as well as their organizations' missions and behaviors (Bess \& Dee, 2008; Hatch \& Schultz, 1997).

Organizational identity is, as a social construct, an idea that each individual holds as to what is enduring, central, and the core of his or her organization (Albert \& Whetten, 1985; Weerts, Freed, \& Morphew, 2014; Whetten, 2006). This construct of organizational identity refers to organizational members' understandings and, subsequently through language (Ayers, 2005; Brown \& Humphreys, 2006), to explanations of the purposes of the organization, the meanings of its behaviours and actions, and, for post-secondary institutions, its social and educational roles (Levin, 1998). Organizational members create explanations of how their organization works (Whetten, 2006), explanations that both highlight and hide specific features of the organization (Boland \& Greenberg, 1988; Morgan, 2006). In the case of higher education institutions, these explanations may relate to the centrality of teaching and research in the organizational mission, the university's connection to the local community, or the university's curricular offerings, for example. 
Each individual's idea of what constitutes the core of their organization informs their perceptions of their own position in the organization and provides meaning to their behaviours (Whetten, 2006; see also Bess \& Dee, 2008); that is, organizational identity provides a frame of reference for an individual's conceptions of their own organizational roles and functions. For university presidents, their position involves intra-organizational and inter-organizational roles (Evan, 1993); that is, the conceptualization of their roles involves understandings of their role in the university and the role of the university for external constituencies (Evan, 1993). Thus, internal (organizational) and external expectations of what a university is, what its functions are, and how these functions should be enacted-the university logic (Levin, 2017)-inform the image that presidents construct of their university as an organization and inform their understandings of their own role in new universities.

Expectations for an organization's identity alone are not the sole shaper of organizational behaviour. Institutional logics (Thornton, Ocasio, \& Lounsbury, 2012) constitute the assumptions and sources of meaning that organizational members adopt when they are socialized in a particular institution, such as a university or college. These institutional logics give rise to organizational behaviours and actions and legitimize them (Scott, 2014). Behaviours that are congruent with an institutional logic reinforce that logic and can lead to legitimate action; those that are not congruent are dissmised or ignored-understood and treated as illegitimate.

The logic of a community college is not the same as the logic of a university (Levin, 2017), and thus an organization's identity as a university entails different behaviours and actions from those of a community college. For organizations that shift their identity from a community college to a university, the institutional logic shifts as well, or there is an identity conflict or crisis. Thornton et al. (2012) accept that the introduction of a new logic-a university logic-into an organization occurs when that new logic replaces an existing logic, or when it blends with the existing logic, or when it stands separate, and segregrated, from the existing logic. In the case of a separation of logics, for example, the university logic may stand apart from the community college logic in the domain of student admissions (i. e., open access) or curriculum (i.e., comprehensive curriculum, including developmental and vocational education). The blending of logics may occur, for example, when a tenure process combines elements of community college logic-excellence in instruction as primary-with university logic-research productivity. The replacement of logics, however, requires the removal or vanquishing of a dominant, central assumption of an institution, such as unicameral governance, and the replacement of that assumption with another-in this case, bicameral governance (Dennison, 2006).

In order to fulfill our purpose, this investigation relied on two main research questions: In what ways do these three presidents of new universities (Levin, 2017) understand their organizational roles and functions? What are the ways in which the presidents understand and articulate the organizational identity of their universities? Thus, this inquiry focuses on the meaning-making and positionality of university presidents.

\section{Methodology and Methods}

In order to capture the perceptions of university presidents, we utilized qualitative field methods (Burgess, 2002) and collected data from one source: interviews (Miles, $\mathrm{Hu}-$ berman, \& Saldaña, 2014). This approach provided us with an opportunity to explore the 
ways in which individuals' positionality influences their attributions of meaning to both their role within new universities and their understandings of the paths to legitimacy that their institutions should take and have taken. This positionality is linked to individuals' previous experiences and the sociocultural contexts of these experiences (Burgess, 2002; Seidman, 2013). These presidents' positionality and their attributions of meaning point to their capacity for reflexivity, whereby they construct narratives of themselves in relation to their institutional contexts (Eisner, 2003; Trahar, 2009).

We centred this investigation on the perceptions and interpretations of social interactions of specific individuals in a particular context (Lichtman, 2013) in order to explain the multiple and complex meanings of social reality that individuals create (Creswell, 2007). Our focus on the participants' experiences, flexibility during data collection, and data analysis of the participants' meanings enabled us to understand and explain the experiences of presidents of new universities through our first-hand contact with presidents (Creswell, 2007; Silverman, 2011).

We chose three new universities, two in British Columbia and one in Alberta, and the principal researcher conducted interviews in 2013 with the president of each university. We selected these three campuses due to their particular circumstances of recent organizational change. That is, they matched the criteria of new universities (Levin, 2017): the two British Columbia universities were established through legislation in 2008, and the one Alberta university was established in 2009. In addition, the principal researcher had knowledge of the three sites due to a research project carried out previously, which provided us with longitudinal information on the historical and cultural background of the three organizations before they became universities.

Historically, Canadian university presidents, predominantly, have been white males, although since the 1980 s, the percentage of women presidents has increased to approximately $19 \%$ (Turpin, 2012). At present, the percentage has dropped slightly to $14 \%$, and there is evidence to indicate that self-identified foreign-born and visible minority presidents have increased in the population of university presidents during the 2000s (Charbonneau, 2010). Of the legislated new universities in Alberta and British Columbia, only one had a female president and none of the presidents were visible minorities during the interview period of this investigation in 2013. In accordance, the three presidents included in this investigation were male and not visible minorities.The specific selection of university presidents had more to do with the fact that their institutions were the subject of an initial investigation that covered the 1989-99 period (Levin, 2001), and this present investigation was designed as a follow-up to that earlier one.

This investigation used narrative interviews as the sole source of data collection (Clandinin \& Connelly, 2000). Interviewees were asked to use their reflexivity to attribute meaning and reconstruct events in their professional lives (Brinkmann \& Kvale, 2015; Trahar, 2009; Webster \& Mertova, 2007). Narrative interviews enabled us to explore the presidents' subjective experiences and understandings, and the reflexivity they used to attribute explanations and meaning to their universities' paths to legitimacy.

We conducted one narrative interview with each university president. Each interview lasted between 60 and 90 minutes. The interviews were carried out as guided conversations (Burgess, 2002), in which the interviewer suggested topics for the interviewees to discuss but permitted interviewees to take the conversations in directions that they 
deemed important (e.g., the role of the provincial government, the president's personal interactions with government officials, the president's relationships with faculty). The interviews focused on exploring the presidents' professional careers, their perceptions of the transition of their organizations from community colleges to universities, and the ways in which the participants understood and perceived the pathways that their institutions addressed and needed to address in order to achieve institutional legitimization as universities.

We analyzed interviews through narrative analysis to capture the stories the three presidents offered about their universities. As well, we coded interview data in line with the images the presidents used to characterize their universities and their own position, or role, in the organization. For narrative analysis we relied upon Riessman $(2002,2008)$. The goal of this analysis was not the generation of narratives but what Bochner and Riggs (2014) have named narrative under analysis. We identified the narratives in which presidents reflected on their university as an organization, on their own background, and on their role as organizational members. Narrative analysis enabled us to explore the participants' stories, experiences, and meanings (Slay \& Smith, 2011) and to convey the historical and social context through the lens of individual perspectives (Maynes, Pierce, \& Laslett, 2012).

For coding, we relied on the concept of image and metaphor derived from Morgan's Images of Organizations (2006). In Morgan's concept, each individual constructs an image of his or her organization that both elevates and ignores specific aspects of the organization and that leads individuals to "manage organizations in distinctive" ways (p. 4). Accordingly, we scanned interviews for two categories of data that included (1) the presidents' image of the central characteristics of their universities as organizations, and (2) the presidents' role in relation to their organization's goals. We used constructs of organizational identity to code the data for the characteristics of the universities; we identified the participants' descriptions of their universities' organizational goals, priorities, needs, and distinctive elements compared to other similar organizations (i.e., universities) (Albert \& Whetten, 1985; Weerts et al., 2014; Whetten, 2006). To code for the presidents' roles, we used constructs of role theory; in each interview, we sought descriptions of the presidents' functions, their inter- and intra-organizational roles, and their relationships with other roles (positions) in the organization (Evan, 1993). Finally, we compared data in both categories to explain the ways in which these presidents understood the legitimation of their institutions. In the presentations of our findings and conclusions, we use pseudonyms for the universities: East Shoreline University (ESU), Rural Valley University (RVU), and North Mountain University (NMU).

\section{Findings}

\section{Backgrounds of the Presidents}

The three presidents were relative newcomers to their institutions, and all three began their tenure after their institutions became universities. All had served previously as faculty and administrators at universities but had no professional experience in community colleges. The three participants' backgrounds coincided with their perspectives and understandings of their role as university leaders. Although other members of their 
organizations had experience with the universities when they were community colleges, prior to 2008 and 2009 (Levin, 2017), the presidents did not express nostalgia for any preferred condition associated with their university's previous community college status. That is, some values of the community college, including open access to further education and responsiveness to the local community, were not adopted or embraced-but were, in fact, rejected-by the three presidents. Instead, the presidents looked to what was missing in their institutions that needed to be addressed in order for their institutions to possess legitimate identities as universities. They noted the developmental phase of their academic senates, the rationalization of research at their institutions, and the challenges with academic rank. However, the presidents' experiences at other universities that had undergone organizational change, as well as the limitations of their current universities (e.g., resources), motivated them to embrace a teaching orientation as a central value of their university. This enabled them to avoid "drift" toward a dominant emphasis on research, the role of a traditional Canadian university. "We're starting to drift away from... what we are now.... What I want to do is stop" (President, NMU). For another president, this teaching orientation and university identity protected him or her from reliance on decisions directed by an "opportunist attitude" (President, ESU) in programming, with the term "opportunistic" as consistent with community college responsiveness and adaptability (Levin, 2017). All three presidents suggested or stated that their institution was not a community college, which indicated that for them traditional community college values and practices were unwelcome.

\section{Roles of the Presidents}

Of considerable significance was the approach taken by all three presidents, which deviated from the scholarly literature, particularly the literature that emphasized the symbolic nature of the presidency (Birnbaum, 1992). In the case of the three presidents in this investigation, their self-projected role was that of guides and directors: because they had previous experience with universities, they could guide and direct faculty and administrators at their institutions on a path to achieve a legitimate identity as a university. Whereas Birnbaum (1992) expected presidents to conform to institutional norms, the three presidents adopted the role of a guide to help organizational members, board members, and their communities reach their aspirational goals: to become a legitimate university. This role entailed development of structures and processes.

The presidents understood that their role was, as well, to define the sector in which their university belonged: "new universities" (President, RVU), "undergraduate universities" (President, NMU), "teaching universities" (President, ESU). The presidents indicated that there were inconsistencies between understandings of universities and their particular organizations, and that these understandings hindered their universities' ability to serve their purposes. Among presidents' functions was the education of policy makers, government officials, and the general public about the specific characteristics of their universities; the creation of internal structures and processes (e.g., academic senate, organizational policies and norms) that shaped members' roles; and the development of their universities' relationships with other universities in the same province.

The President of Rural Valley University understood his role as predominately concerned with the legitimization of his organization as a university, and the need to differen- 
tiate it from a college. One major action for this was his role as the developer of a bicameral governance system, particularly through the creation of a senate. "I have...drawn... people back to the act [University Act], to the legislation that defines not only powers but responsibilities.... I've insisted that the committees be weighted in favour of faculty membership.... In...our senate committees...a faculty member...will chair it." His background as a university administrator gave him experiential knowledge of the responsibilities of faculty in bicameral governance. Other than his role here in governance, he used the first person plural noun ("we"), but it is clear that he means that his role functions in concert with others:

I don't want this to sound as if I'm doing this all alone as the great messiah. There were many people...who had the vision, saw the [university] model, recognized the importance and embraced these opportunities.... We reached out to others.

He included others in his public efforts to educate provincial government officials and the public: "We are working to help government and the public understand our mandate, understand what we do well, understand the strengths of our system."

The President of North Mountain University understood that a component of his role was not just to ensure his university's legitimacy but to bring prominence. In part, he wanted his university to be known for its teaching, but he wanted a national reputation as the "best" university of its kind:

I'd like to have the profile of students that Mount Allison does from across the country but offer the broader array of programs and research opportunities and learning experiences.... Being the best increases our national reputation...increases the quality of students we can have...increases our opportunities to develop scholarships and have people in the community willing to give us scholarships.... That will increase our reputation...[and] the opportunity for internationalism.... Being the best also means what opportunities do we have that we provide to our own students.

This prominence would be a result of the president's role in such diverse actions as increasing teaching effectiveness; increasing the participation of faculty in governance; bringing in money to support undergraduate education; and negotiating with government officials, and the minister in particular, to improve his university's resources and fulfill internal goals. Although a number of actions, such as limiting faculty's participation in research, were clearly not ones that a president could carry out alone, the NMU president did not say that these responsibilities were within the role expectations or duties of others; rather, he stated or implied that these were his roles. Thus, as well as his role as guide, particularly in socializing administrators and faculty in university policies and practices, the president viewed his role as both director of actions and the actor of specific actions.

The President of East Shoreline University articulated his role as largely consonant with that of a manager of a business, comprising leadership, planning, negotiating, and resource acquisition, as well as educating university members on the expected functioning of a university. In discussing his role, he used the first person plural noun ("we"), which reinforced his managerial role in that he hired and directed personnel. Planning was one key area: 
This integrating planning notion is very important to us...It provides us with a collective understanding of where we come from...where we're going, and what we're trying to build here.... We tried to get people to take the responsibility to participate.

Another area was economic development of the local community:

We're defining ourselves in this region as a key economic driver, as a key to success.... We line up with the economic development commission. We line up with all the mayors and councilors.... We're a key part of [the] Science and Technology Council.... We're a key driver there.

A third area of the president's role was as articulator of values:

We've got a set of values...here. And we hold those up. And we've been that much sharper in articulating.... We've got a new HR person...that really helped us. That's important to people, knowing that they're a part of a place that really lives and breathes its values across the institution.

The ESU president represented himself not only as a guide but also as the head of his organization, in charge of the university's activities and actions.

\section{Presidents' Conceptions of the Organizational Identity of Their Universities: Identities Under Construction}

The President of North Mountain University viewed his university as a teaching university, with emphasis on undergraduate education: "I think our differentiator is that we are an undergraduate only institution.... Why can't we be the best undergraduate program in the province or country?" He wanted limits on the introduction of graduate programs: "What happened [elsewhere]...you went gung-ho into graduate planning and you essentially robbed what was your differentiator, which was your key driver, which was the fact [of] undergraduate students." He noted as well that NMU had to take on the role of a university, as it had shed its former identity as a college: "We're a university now, not a college." What limits the development of this new status and identity is the cultural divide among faculty, essentially between those who were aligned with the former identity of the institution as a college and those aligned with the aspirational identity of a legitimate and publicly recognized university:

The biggest issue...the faculty is facing is not a faculty versus admin; it's a faculty versus faculty. There's a growing gulf between faculty who...have been around a long time...who have always seen themselves primarily as college instructors; who love what they do; who are great at what they do, but are feeling pushed out by the young folks who are teaching less and doing more research and don't value teaching. The...profile of faculty we've hired pre-degree granting and post, it's huge.... There is a cultural divide within the faculty.

The construction of a university identity for the President of NMU, then, depended on organizational members' commitment to a collective mission as a prestigious undergraduate university, with excellence in teaching, and on cultural change, including closing the gap between two tiers of faculty. 
The President of Rural Valley University understood his institution as neither research university nor college. Unlike colleges, the president noted, "our needs are different, our expectations are different, governance structure is different." Unlike traditional Canadian research universities, his university was "establishing standards for tenure and promotion that are distinctly different from that of a research university." He included himself in this development:

We're working hard to establish standards which will focus on what we believe is most important.... Our rank and tenure agreement...puts teaching excellence in the center. It includes the service and scholarship/research obligations but it's teaching excellence that we've put at the core of the model.

The process of becoming a university requires faculty as decision makers, replacing administrators in that role to some extent. Bicameral governance, while the norm in Canadian universities (Levin, 2017), requires a university to develop more than a structure:

You can create a senate and put members in place, but working with a senate and the board [means that]...people [have to] understand in this bicameral governance structure...[t]he senate does not report to the board; the senate has different powers, but it has specific powers that is the endpoint for certain decisions.

It was thus the self-appointed role of the President of RVU to ensure that authentic bicameral governance was enacted. The construction of a university, for the President of RVU, was a developmental process, which demanded not just the institutionalization of structures and processes but the adequate, even highly collaborative, functioning of those structures and processes.

The President of East Shoreline University viewed his institution's identity through the eyes of many of the faculty, seeing it as not yet a university but entrenched in its college history and culture:

"You're a university in all but name only." That was what I heard.... And these were people who had never been at a university; they didn't know anything about government structures, knew nothing about responsibilities, knew nothing about faculty responsibilities, nothing about...the peer review, and the importance of peer review in the university.

As a result of this level of organizational members' inexperience or ignorance, the President of ESU saw himself as the director of the establishment of bicameral governance, faculty rank, and peer evaluation. The community college ethos of collegiality and equality was giving way to a university culture of merit. "The pressure is more about 'we're all the same...there are no stand outs here.' You know this tall poppy thing, you clip them down.... We're emerging out of that." Furthermore, the former college culture, with a strong union presence, continued on to the present, several years after the university designation. "Department heads have very little responsibility compared to [traditional universities]. That's part of the union controlling management. What had crept in here was a co-management model that didn't align with the new university act." But alteration to this condition was underway. "The union was the opposition to the board. And that's a 
significant change that has happened now, where the senate has responsibility for quality that the union can't stand up and say: 'Where [is] the quality?'” The construction of a university identity, then, for ESU's president, was also a process of de-construction: The undoing of community college attributes and past practices that contradicted notions of what it means to be a university.

The three presidents understood their universities as undergoing a process of identity development: Their university was an unfinished institution. In general, their universities either lacked legitimate structures or processes that would identify them as universities, or they constituted an organizational culture that was fragmented (Morgan, 2006) or unambiguous (Martin \& Meyerson, 1988). At one university, ESU, the fragmented culture was in part a consequence of faculty subcultures that did not accept either the president's efforts to deconstruct the organization's attributes or his approaches to management. This led to considerable unrest, which the president saw as a battle of values: "We respect that they've got jobs to do. We've got jobs to do. We'll battle very clearly; we'll battle and hold our line on principle." Identity development, then, was a process of culture formation on the one hand and a process of cultural unity on the other. It also entailed the deliberate eradication of certain subcultures, particularly in the case of ESU.

\section{Conclusions and Implications}

The organizational identity of the three universities, as seen through the perceptions of the three presidents, suggests that these three organizations were developing institutions in an adolescent phase of an organizational life cycle (Cameron, 1984). Furthermore, they were engaged in a replacement of institutional logics. The judgements of the three presidents were in large part a consequence of their experiences in traditional Canadian universities and their inexperience in community colleges. The presidents recognized those aspects of their universities that did not align with notions of a university and those aspects that were in need of development or alteration so that their universities could be viewed as legitimate. Of the three presidents, the North Mountain University president considered his organization a university, de facto, whereas the other two presidents, at best, viewed their organizations as simply de jure universities, which were in need of significant alteration. None of the three indicated that their organizations had embraced, fully, the logic of the university; however, the President of NMU acknowledged that his organization had rid itself of numerous attributes of a community college, including open access, and had institutionalized faculty rank, even though categories and criteria were changeable (Levin, 2017). The other two presidents saw their universities as engaged in a process of deinstitutionalization of community college attributes and values, such as a non-hierarchical faculty structure where all faculty are referred to as "instructor," rather than as assistant, associate, and full professor.

Evidently, the alteration from the institutional logic (Hinings, 2012; Scott, 2014) of a community college to the institutional logic of a university was neither straightforward nor unproblematic. Although Dennison (2006) decried the change of community colleges in Canada to baccalaureate degree-granting institutions, which at the time he considered an institutional transitional phase of colleges becoming universities, he was prescient enough to understand the legitimacy dilemma that would ensue if these colleges were legislated as universities: "An attempt to emulate the characteristics of established uni- 
versities is unlikely to succeed" (p. 122). He noted that if these colleges became universities, they would have to be viewed as special-purpose universities:

The task will be to demonstrate that an innovative approach to curriculum design, organization and management, instructional technology, or workplace-oriented practices may be conducted without compromising quality. Each "new" university will adopt a model that best accommodates the needs of its particular students, its community and the reputation it hopes to build. Credibility in academia is not awarded by changing the name of the institution, nor by investing in public relations, but by ensuring excellence in its graduates and the performance of its instructional faculty. (Dennison, 2006, p. 122)

Here, indeed, is advice for our three presidents and their organizations, as well as other higher educational institutions undergoing sectoral change to university status: there may have to be a blending of institutional logics, not a replacement of one logic with another (Thornton et al., 2012), in order for new universities to achieve credibility among other universities and the public. This suggests that presidents with experience in community colleges may have an advantage in aiding their organizations in transition from college to university, and perhaps that presidents should refrain from insisting upon a replacement of logics and prefer instead to guide their organization through a blending of logics. In the case of two of the universities-East Shoreline University and Rural Valley Universitythis blending was enshrined in legislation, so that the universities provided curriculum that was decidedly both associated with community colleges (e.g., adult basic education, trades) and universities (baccalaureate and master's degree programming). The blending of logics also involves a change in organizational culture-the latent assumptions, values, and philosophies (Burnett \& Huisman, 2010) of a campus. Culture at these three universities was both ambiguous and contested, from the presidents' point of view. Organizational culture is the context "within which interpretations of organizational identity are formed" (Hatch \& Schultz, 1997, p. 357). Thus, future research might focus on new universities as "hybrid organizations" (Whetten, 2006) with multiple organizational cultures and organizational identities.

For scholars and researchers who address university presidents, this investigation demonstrates that presidents' backgrounds shape their perceptions and ultimately their actions, and that organizational identity both shapes and is shaped by presidents, at least in their own eyes. For these three presidents, who were initially outsiders in their organizations and outsiders to their organizations' historical culture, their perceptions were not the subject of personal doubt or self-questioning. They claimed responsibility for the enactment of specific actions directed at specific goals: to institutionalize university structures and processes and to legitimize their organization as a university. Unlike Birnbaum's symbolic figure (1992), these presidents fashioned themselves as Mintzberg's managers (1973), who act and commit their organizations to action.

\section{References}

Albert, S., \& Whetten, D. A. (1985). Organizational identity. Research in Organizational Behavior, 7, 263-295. 
Amey, M. J., \& VanDerLinden, K. E. (2002). Career paths for community college leaders. (Research Brief Leadership series, no. 2). Washington, DC: American Association of Community Colleges.

Ayers, D. (2005). Organizational climate in its semiotic aspect: A postmodern community college undergoes renewal. Community College Review, 33(1), 1-21.

Baldridge, J., Curtis, D., Ecker, G, \& Riley, G. (1980). Policymaking and effective leadership. San Francisco, CA: Jossey-Bass.

Bess, J., \& Dee, J. (2008). Understanding college and university organization: Theories for effective policy practice (Vol. 1, 1st ed.). Sterling, VA: Stylus.

Birnbaum, R. (1988). How colleges work: The cybernetics of academic organization and leadership. San Francisco, CA: Jossey-Bass.

Birnbaum, R. (1989a). The implicit leadership theories of college and university presidents. Review of Higher Education, 12(2), 125-136.

Birnbaum, R. (1989b). Presidential succession and institutional functioning in higher education. Journal of Higher Education, 6o(2), 123-135.

Birnbaum, R. (1992). How academic leadership works: Understanding success and failure in the college presidency. San Francisco, CA: Jossey-Bass.

Birnbaum,R.(1994).Thequalitycube:Howcollegepresidentsassess excellence.Journal of Tertiary Education Administration, 16(1), 69-79.

Birnbaum, R., \& Umbach, P. D. (2001). Scholar, steward, spanner, stranger: The four career paths of college presidents. The Review of Higher Education, 24(3), 203-217.

Bochner, A. P., \& Riggs, N. A. (2014). Practicing narrative inquiry. In P. Leavy (Ed.), The Oxford handbook of qualitative research (pp. 195-222). New York, NY: Oxford University Press.

Boland, R. J., \& Greenberg, R. H. (1988). Metaphorical structuring of organizational ambiguity. In L. R. Ondy, R. Boland, \& H. Thomas (Eds.), Managing ambiguity and change (pp. 17-36). New York, NY: John Wiley \& Sons.

Brinkmann, S., \& Kvale, S. (2015). Interviews: Learning the craft of qualitative research interviewing (3rd ed.). Thousand Oaks, CA: Sage Publications.

Brown, A. D., \& Humphreys, M. (2006). Organizational identity and place: A discursive exploration of hegemony and resistance. Journal of Management Studies, 43(2), 231257.

Budros, A. (2002). Do university presidents make a difference? A strategic leadership theory of university retrenchment. The Canadian Journal of Higher Education, 32(1), 91-124.

Burgess, R. G. (2002). In the field: An introduction to field research. New York, NY: Routledge.

Burnett, S.-A., \& Huisman, J. (2010). Universities' responses to globalisation: The influence of organisational culture. Journal of Studies in International Education, 14(2), 117-142. 
Cameron, K. (1984). Organizational adaptation and higher education. The Journal of Higher Education, 55(2), 122-144.

Charbonneau, L. (2010, November 25). The new face of Canadian university presidents. University Affairs: Margin Notes Blog. Retrieved from http://www.universityaffairs.ca/ opinion/margin-notes/the-new-face-of-canadian-university-presidents/.

Clandinin, D. J., \& Connelly, F. M. (2000). Narrative inquiry: Experience and story in qualitative research. San Francisco, CA: Jossey-Bass.

Clark, B. (1972). The organizational saga in higher education. Administrative Science Quarterly, 17(2), 178-184.

Cohen, M. D., \& March, J. G. (1974). Leadership and ambiguity: The American college president. Hightstown, NJ: McGraw-Hill.

Corley, K. G. (2004). Defined by our strategy or our culture? Hierarchical differences in perceptions of organizational identity and change. Human Relations, 57(9), 1145-1177.

Creswell, J. W. (2007). Qualitative inquiry \& research design: Chosing among five approaches (2nd ed.). Thousand Oaks, CA: Sage Publications.

Dee, J. R., Henkin, A. B., \& Holman, F. B. (2004). Reconciling differences: Conflict management strategies of Catholic college and university presidents. Higher Education, 47(2), 177-196.

Dennison, J. (2006). From community college to university: A personal commentary on the evolution of an institution. Canadian Journal of Higher Education, 36(2), 107124 .

Eisner, E. W. (2003). On the art and science of qualitative research in psychology. In P. M. Camic, J. E. Rhodes, \& L. Yardley (Eds.), Qualitative research in psychology: Expanding perspectives in methodology and design (pp. 17-29). Washington, DC: American Psychological Association.

Esters, L. T., Washington, A., Gasman, M., Commodore, F., O’Neal, B., Freeman S., Jr., Carter, C., \& Jimenez, C. D. (2016). Effective leadership: A toolkit for the 21stcentury historically black college and university president. Philadelphia, PA: Penn State University Graduate School of Education. Retrieved from https://cmsi.gse.upenn.edu/ sites/default/files/MSI_LdrshpRprt_R3.pdf

Evan, W. M. (1993). Organizational theory, research and design. New York, NY: The Free Press.

Freeman, S., Jr., \& Kochan, F. K. (2013). University presidents' perspectives of the knowledge and competencies needed in 21st century higher education leadership. Journal of Educational Leadership in Action, 1(1), 1-20.

Gioia, D. A., Price, K. N., Hamilton, A. L., \& Thomas, J. B. (2010). Forging an identity: An insider-outsider study of processes involved in the formation of organizational identity. Administrative Science Quarterly, 55(1), 1-46.

Green, M. F. (1988). A profile of the American college president. Educational Record, 69(2), 44-48. 
Hatch, M. J., \& Schultz, M. (1997). Relations between organizational culture, identity, and image. European Journal of Marketing, 31(5), 256-365.

Havice, P. A., \& Williams, F. K. (2005). Achieving balance: Lessons learned from university and college presidents. College Student Affairs Journal, 24(2), 128-136.

Hinings, B. (2012). Connections between institutional logics and organizational culture. Journal of Management Inquiry, 21(1), 98-101.

Kerr, C., \& Gade, M. (1986). The many lives of academic presidents. Washington, DC: Association of Governing Boards of Universities and Colleges.

Levin, J. S. (1992). The paradox of the presidency: The difference a president makes in institutional functioning at three community colleges. Canadian Journal of Higher Education, 22(3), 28-45.

Levin, J. S. (1995). The community college presidency: Conditions and factors of impact on an institution. Community College Journal of Research and Practice, 19(5), 411-422.

Levin, J. S. (1998). Presidential influence, leadership succession and multiple interpretations of organizational change in the community college. Review of Higher Education, 21(4), 405-425.

Levin, J. S. (2001). Globalizing community college: Strategies for change in the twenty-first century. New York, NY: Palgrave.

Levin, J. S. (2017). Community college and new universities under neoliberal pressure: Organizational change and stability. New York, NY: Palgrave MacMillan

Levin, J. S., Aliyeva, A., \& Walker, L. (2016). From community college to university: Institutionalization and neoliberalism in British Columbia and Alberta. Canadian Journal of Higher Education, 46(2), 165-180.

Levin, J. S., López-Damián, A. I., Rall, R., Martin, M. C., \& Viggiano, T. (2016, May). The logics of business and the logics of post-secondary education: Neoliberal policies in Canadian national and provincial policy. Research paper presented at the annual conference of the Canadian Society for the Study of Higher Education, Calgary, AB.

Levin, J. S., Martin, M. C., López-Damián, A. I., Rall, R., \& Viggiano, T. (2016, May). Crisis of identity? New universities in Canada. Research paper presented at the annual conference of the Canadian Society for the Study of Higher Education, Calgary, AB.

Levin, J. S., Rall, R. M., Viggiano, T., \& López-Damián, A., (2016, April). From unicameral to bicameral governance through sectoral change in higher education: New universities in Canada. Research paper presented at the annual general meeting of the American Educational Research Association, Washinton, DC.

Lichtman, M. (2013). Qualitative research in education: A user's guide (3rd ed.). Thousand Oaks, CA: Sage Publications.

Madsen, S. R. (2006, May). Women university presidents: Career paths and educational backgrounds. Paper presented at the European Academy of Management, Oslo, Norway. Retrieved from https://works.bepress.com/susan_madsen/18/download/ 
Martin, J., \& Meyerson, D. (1988). Organizational cultures and the denial, channeling and acknowledgment of ambiguity. In L. R. Pondy, R. J. Boland, \& H. Thomas (Eds.), Managing ambiguity and change (pp. 93-125). New York, NY: John Wiley \& Sons.

Maynes, M. J., Pierce, J. L., \& Laslett, B. (2012). Telling stories: The use of personal narratives in the social sciences and history. Ithaca, NY: Cornell University Press.

McQuarrie, F. A., Kondra, A. Z., \& Lamertz, K. (2013). Government, coercive power and the perceived legitimacy of Canadian post-secondary institutions. The Canadian Journal of Higher Education, 43(2), 149-165.

Miles, M., Huberman, A. M., \& Saldaña, A. (2014). Qualitative data analysis: A sourcebook of new methods (3rd ed.). Thousand Oaks, CA: Sage Publications.

Miller,H.(1998).ManagingacademicsinCanadaandtheUnited Kingdom.International Studies in Sociology of Education, 8(1), 3-24.

Mintzberg, H. (1973). The nature of managerial work. New York, NY: Harper \& Row.

Monks, J. (2007). Public versus private university presidents pay levels and structure. Economics of Education Review, 26(3), 338-348.

Moore, K. M., Salimbene, A. M., Marlier, J. D., \& Bragg, S. M. (1983). The structure of presidents' and deans' careers. The Journal of Higher Education, 54(5), 500-515.

Morgan, G. (2006). Images of organization. Thousand Oaks, CA: Sage Publications.

Mount, J., \& Bélanger, C. (2001). "Academia, Inc": The perspective of university presidents. The Canadian Journal of Higher Education, 31(2), 135-166.

Muzzin, L. J., \& Tracz, G. S. (1981). Characteristics and careers of Canadian university presidents. Higher Education, 10(3), 335-351.

Nicholson, W. D., II. (2007). Leading where it counts: An investigation of the leadership styles and behaviors that define college and university presidents as successful fundraisers. International Journal of Educational Advancement, 7(4), 256-270.

Padilla, A. (2005). Portraits in leadership: Six extraordinary university presidents. Westport, CT: Praeger Publishers.

Pfeffer, J., \& Ross, J. (1988). The compensation of college and university presidents. Research in Higher Education, 29(1), 79-91.

Riessman, C. K. (2002). Analysis of personal narratives. In J. F. Gubrium \& J. A. Holstein (Eds.), Handbook of interview research: Context and method (pp. 695-710). Thousand Oaks, CA: Sage Publications.

Riessman, C. K. (2008). Narrative methods for human sciences. Thousand Oaks, CA: Sage Publications.

Scott, S. G., \& Lane, V. R. (2000). A stakeholder approach to organizational identity. Academy of Management Review, 25(1), 43-62.

Scott, W. R. (2014). Institutions and organizations. Ideas, interests, and identities (4th ed.). Thousand Oaks, CA: Sage.

Seidman, I. (2013). A structure for in-depth, phenomenological interviewing. In I. 
Seidman (Ed.), Interviewing as qualitative research: A guide for researchers ineducation and the social sciences (pp. 81-114). New York, NY: Teachers College Press.

Silverman, D. (2011). Interpreting qualitative data (4th ed.). Thousand Oaks, CA: Sage Publications.

Slaughter, S. (1993). Beyond basic science: Research university presidents' narratives of science policy. Science, Technology, \& Human Values, 18(3), 278-302.

Slay, H. S., \& Smith, D. A. (2011). Professional identity construction: Using narrative to understand the negotiation of professional and stigmatized cultural identities. Human Relations, 64(1), 85-107.

Smerek, R. (2010). Sensemaking and sensegiving: An exploratory study of the simultaneous "being and learning" of new college and university presidents. Journal of Leadership \& Organizational Studies, 18(1), 80-94.

Tang, T. L. P., Tang, D. S. H., \& Tang, C. S. Y. (2000). Factors related to university presidents' pay: An examination of private colleges and universities. Higher Education, 39(4), 393-415.

Thornton, P. H., Ocasio, W., \& Lounsbury, M. (2012). The institutional logics perspective: A new approach to culture, structure, and process. New York, NY: Oxford University Press.

Tierney, W. G. (1989). Symbolism and presidential perceptions of leadership. The Review of Higher Education, 12(2), 153-166.

Trahar, S. (2009). Beyond the story itself: Narrative inquiry and autoethnography in intercultural research in higher education. Forum: Qualitative Social Research, 1O(1). http://dx.doi.org/10.17169/fqs-10.1.1218.

Turpin, D. H. (2012, April). Canadian university presidents project. Report presented to members of the Asociation of Universities and Colleges of Canada, Ottawa, ON.

Webster, L., \& Mertova, P. (2007). Using narrative inquiry as a research method: An introduction to using critical event narrative analysis in research on learning and teaching. New York, NY: Routledge.

Weerts, D. J., Freed, G. H., \& Morphew, C. C. (2014). Organizational identity in higher education: Conceptual and empirical perspectives. In M. Paulsen (Ed.), Higher education: Handbook of theory and research (Vol. 29, pp. 229-278). Dordrecht, Germany: Springer. doi:10.1007/978-94-017-8005-6_6.

Wessel, R. D., \& Keim, M. C. (1994). Career patterns of private four-year college and university presidents in the United States. The Journal of Higher Education, 65(2), 211225 .

Whetten, D. A. (2006). Albert and Whetten revisited: Strengthening the concept of organizational identity. Journal of Management Inquiry, 15(3), 219-230.

Yeo, M., Bennett, D., Stoneman McNichol, J., \& Merkley, C. (2015). New faculty experience in times of institutional change. Canadian Journal of Higher Education, 45(4), 283-297. 


\section{Contact Information}

Marie C. Martin

University of California, Riverside

mmartin@ucx.ucr.edu

John S. Levin is Professor of Higher Education in the Graduate School of Education, University of California, Riverside. He is a widely published scholar in the United States and an acknowledged expert on community colleges in both the U.S. and Canada. His most recent book is Community Colleges and New Universities under Neoliberal Pressures: Organizational Change and Stability. His next book addresses the management of the academic profession. He is a former community college faculty member and administrator in Canada.

Ariadna I. López Damián completed a PhD in Higher Education Administration and Policy at the University of California, Riverside. Her research interests include the work experiences of part-time faculty in Mexico and the United States, higher education institutions' organizational identity, and person-environment fit for faculty and students at diverse institutional types. She completed her doctoral dissertation on work engagement of long-term part-time faculty at public universities in California.

Marie C. Martin completed a PhD in Higher Education Administration and Policy at the University of California, Riverside. She is the Director of Academic Services at the University of California, Riverside Extension Center. Her research focuses on faculty, higher education management, and the intersections of academic and administrative spheres. Her dissertation explained the ways in which deans at research universities use their academic identity to embrace, reject, and cope with neoliberal ideologies.

Evelyn Morales Vázquez is a PhD candidate in the Higher Education Administration and Policy Program at the University of California, Riverside. Her current research focuses on the study of professional identities and emotions in the academic life cycle. 